\title{
HYGROTHERMAL ANALYSIS OF WINDOW CONSTRUCION JOINTS
}

\author{
Balázs Nagy ${ }^{1}$ \\ Cecília Tömböly ${ }^{2}$
}

UDK: 699.8:674.21

DOI: $10.14415 /$ konferencijaGFS2018.008

Summary: In accordance with current energetic requirements, building construction joints developed significantly in the past few years due to new construction materials and building elements, due to the need for increased thermal insulations and the development of new building technology solutions. Window constructions also developed significantly, however, it is observable that mostly thermal aspects were considered, e.g. reducing thermal bridging around the joints. This paper presents comparative analysis of steady-state multidimensional conjugated heat- and moisture transport numerical FEM simulations of insulated wall and window sill, -lintel and horizontal sections. Two different type of wall insulations were also tested, and the effects of the joints' thermal and moisture bridges were evaluated. The results shows how different, well insulated designs of window joints behave differently in the thermal and moisture aspect of view, when expanded polystyrene or mineral wool insulation come around the joints.

Keywords: heat and moisture transfer, building constructions, window joints, thermal bridges, moisture bridges

\section{INTRODUCTION}

The energy consumed by buildings, consisting of residential and commercial end users, accounts for $20.1 \%$ of the total energy consumed worldwide. This value is expected to increase by an average of 1.5\%/year between 2012 and 2040 [1]. Therefore, thermal insulation of new and existing buildings is an extremely important, because it reduces the energy demand of buildings and saves carbon emissions [2]. The EU has set a longterm goal of reducing greenhouse gas emissions by 80-95\%, when compared to 1990 levels, by 2050 [3], therefore building regulations and the requirements of performance certifications of buildings are constantly tightening in the EU [4] making tougher thermal insulation standards for new and existing buildings inevitable. The more stringent thermal transmittance requirements induces new building construction joint solutions too. In Hungary, U-value requirements of façade walls are $0.24 \mathrm{~W} / \mathrm{m}^{2} \mathrm{~K}$, and

\footnotetext{
${ }^{1}$ Balázs Nagy, PhD candidate, Budapest University of Technology and Economics, Faculty of Civil Engineering, Department of Construction Materials and Technologies, Müegyetem rkp. 3. K.I.85., H-1111, Budapest, Hungary, e - mail: nagy.balazs@epito.bme.hu

${ }^{2}$ Cecília Tömböly, Assistant Lecturer, Budapest University of Technology and Economics, Faculty of Civil Engineering, Department of Construction Materials and Technologies, Müegyetem rkp. 3. K.I.85., H-1111, Budapest, Hungary, e - mail: tomboly.cecilia@epito.bme.hu
} 
Савремена достигнућа у грађевинарству 20. април 2018. Суботица, СРБИЈА

for standard plastic or wood framed windows are as low as $1.15 \mathrm{~W} / \mathrm{m}^{2} \mathrm{~K}$, and glazing are $1.0 \mathrm{~W} / \mathrm{m}^{2} \mathrm{~K}$ [5], therefore triple glazed insulated windows are essential in new constructions or in refurbishments. Most of the new or refurbished wall constructions include thick insulation layer from the external side to meet the rigorous thermal transmittance requirements, however there is no linear thermal transmittance, or any moisture related requirements in the regulation. Thermal bridges are considered, where heat flux magnitude changes, compared to its surrounding, and represented in the building performance calculations using linear thermal transmittance. In this analogue, we can introduce moisture bridges, where moisture flux magnitude changes, compared to its surroundings. Architects and engineers design building construction joints mostly to reduce thermal bridging in buildings [6-8], but moisture bridges are not yet evaluated deeply. In this paper, we deal with thermal and moisture bridges of typical new and refurbished triple glazed wood framed window construction joints comparing different constructions to each other.

\section{WINDOW CONSTRUCTION JOINTS}

We created three different window constructions, with three different sections: lintel, sill and horizontal (Fig. 1.). In all models, we used $30 \mathrm{~cm}$ thick masonry blocks insulated with $15 \mathrm{~cm}$ expanded polystyrene (EPS) or mineral wool (MW) insulation.

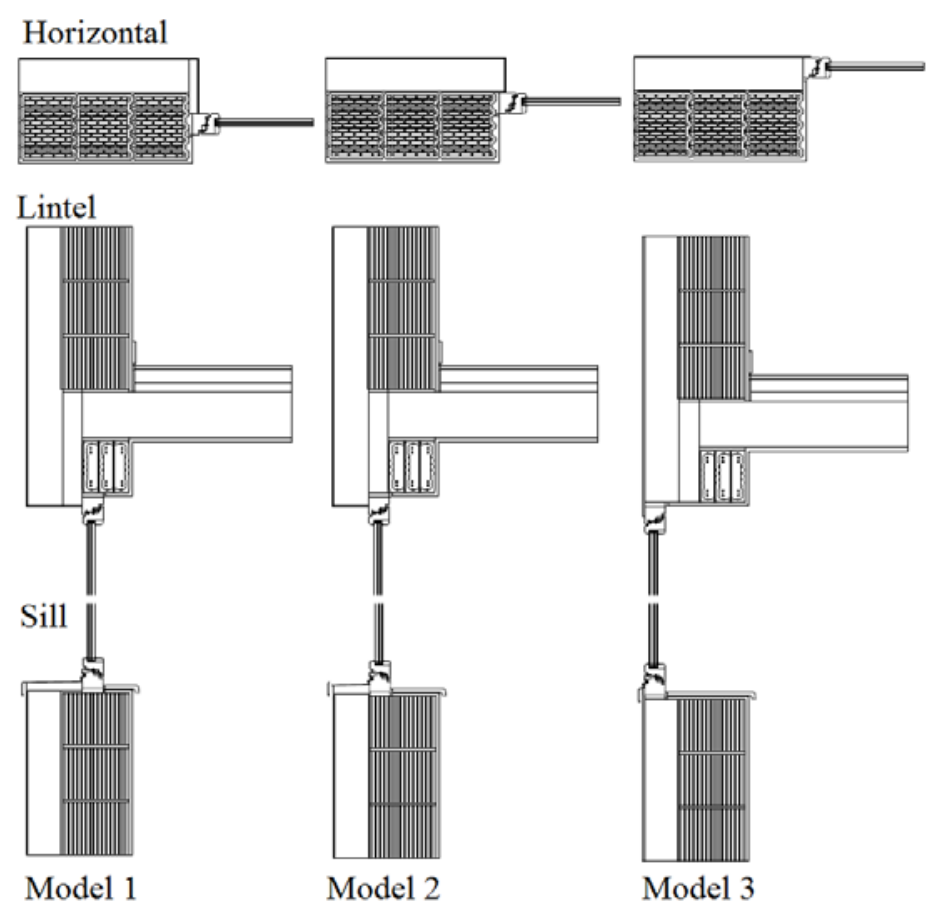

Figure 1. Three different sectional geometry model of three window construction joints 
Contemporary achievements in civil engineering 20. April 2018. Subotica, SERBIA

The first model is where the new window remains in the middle of the wall, and additional insulation is placed on the edge of the wall to reduce thermal bridging. The second construction is where the new window is placed on the edge external of the masonry wall and the thermal insulation layer is overhung on the frame to reduce thermal bridging effects. In the third construction model, the new window is placed completely outside to the outer plane of the thermal insulation, which construction design improves solar exposure and reduce thermal bridging to the minimum. The windows are made out of spruce with three sealing between the fix and winged frames, and the windows are triple glazed with two low-e and argon gas $\left(\mathrm{U}_{\mathrm{g}}=0.6 \mathrm{~W} / \mathrm{m}^{2} \mathrm{~K}\right)$. All window joints constructed using closed cell polyurethane foam (PUR foam) as sealing and insulation between the frame and the wall. We used internal gypsum plaster and thin fine plaster layer on the external insulation. According to the previous mentioned details, 18 models were created.

\section{MULTIDIMENSIONAL HEAT AND MOISTURE TRANSPORT MODELLING}

In this paper, the physics of steady-state conjugated heat and moisture transport in porous media was considered. The partial differential equations (PDE) based on European Standard EN 15026:2007 [9] and solved using Comsol Multiphysics finite element method (FEM) software [10], which allowed the complex geometries. The PDE for steady-state heat transfer is the following:

$$
\begin{gathered}
\nabla \cdot \mathrm{q}=\mathrm{Q} \\
\mathrm{q}=-d_{z}\left(\lambda_{\text {eff }} \cdot \nabla \cdot \mathrm{T}+\mathrm{L}_{\mathrm{V}} \cdot \delta_{p} \cdot \nabla \cdot\left(\phi \cdot \mathrm{p}_{\text {sat }}\right)\right)
\end{gathered}
$$

where $\nabla$ is nabla vectorial differential operator, q is heat flux $\left[\mathrm{W} / \mathrm{m}^{2}\right], \mathrm{Q}$ is heat source $\left[\mathrm{W} / \mathrm{m}^{3}\right], \mathrm{d}_{\mathrm{z}}$ is the thickness of the model which was set to $1 \mathrm{~m}, \lambda_{\text {eff }}$ is temperature and moisture dependent effective thermal conductivity [W/mK] set according to WUFI onedimensional heat and moisture transfer simulation software's material database [11], $\mathrm{T}$ is temperature $[\mathrm{K}], \mathrm{L}_{\mathrm{v}}$ is latent heat of evaporation of water $[\mathrm{J} / \mathrm{kg}], \delta_{\mathrm{p}}$ is vapour permeability $[\mathrm{g} / \mathrm{msPa}], \phi$ is relative humidity [1] and $\mathrm{p}_{\text {sat }}$ is the saturation pressure of water vapour $[\mathrm{Pa}]$. The PDE for moisture transfer is the following:

$$
\begin{gathered}
\nabla \cdot g=G \\
g=-d_{z}\left(\xi \cdot D_{w} \cdot \nabla \cdot \phi+\delta_{p} \cdot \nabla \cdot\left(\phi \cdot \mathrm{P}_{s a t}\right)\right) \\
\xi=\frac{\partial w}{\partial \phi}
\end{gathered}
$$

where $\mathrm{g}$ is moisture flux $\left[\mathrm{kg} / \mathrm{m}^{2} \mathrm{~s}\right], \mathrm{G}$ is moisture source $\left[\mathrm{kg} / \mathrm{m}^{3} \mathrm{~s}\right]$, $\xi$ is differential moisture capacity $\left[\mathrm{kg} / \mathrm{m}^{3}\right], D_{w}$ is moisture diffusivity $\left[\mathrm{m}^{2} / \mathrm{s}\right]$ and $\mathrm{w}$ is the moisture content $\left[\mathrm{kg} / \mathrm{m}^{3}\right]$ according to the hygroscopic sorption isotherms of the materials.

We included all hygrothermal material properties' dependency of temperature and moisture in the material models, such as thermal conductivity, vapour permeability, and 
moisture diffusivity (for capillary active materials, e.g. concrete, masonry, and plasters) and were set based on and according to [11].

The boundary conditions for adiabatic (eq. 6) and for heat flux (eq. 7) are the following:

$$
\begin{gathered}
-\mathbf{n} \cdot d_{z} q_{0}=0 \\
-\mathbf{n} \cdot d_{z} q_{0}=h_{g}\left(T_{a i r}-T\right)
\end{gathered}
$$

where $\mathrm{q}_{0}$ is the inward heat flux $\left[\mathrm{W} / \mathrm{m}^{2}\right], \mathrm{h}_{\mathrm{s}}$ is the heat transfer coefficient $\left[\mathrm{W} / \mathrm{m}^{2} \mathrm{~K}\right]$ according to EN ISO 100077-2 [12]. $\mathrm{T}_{\text {air }}$ is internal air temperature in steady-state conditions set to $293.15 \mathrm{~K}\left(20^{\circ} \mathrm{C}\right)$ and external temperature set to $268.15 \mathrm{~K}\left(-5^{\circ} \mathrm{C}\right)$ according to MSZ 24140:2015 [13]. Initial conditions was set to $20^{\circ} \mathrm{C}$ through the whole domain. These temperatures are the standard, when surface condensation is tested. According to $[14,15]$, the moisture transfer boundary conditions are the following:

$$
\begin{gathered}
-\mathbf{n} \times d_{z} g_{0}=0 \\
-\mathbf{n} \times d_{z g_{0}}=\beta_{p} h_{c}\left(\Phi_{\text {air }} \times \mathrm{p}_{\text {sat }}\left(T_{\text {air }}\right)-\phi \times \mathrm{p}_{\text {sat }}(T)\right)
\end{gathered}
$$

where $\beta_{\mathrm{p}}$ constant is $7.7 \cdot 10^{-9}\left[\mathrm{kgK} / \mathrm{WsPa}\right.$ which if multiplied by $\mathrm{h}_{\mathrm{c}}$ convective heat transfer coefficient gives the moisture transfer coefficient $\left[\mathrm{kg} / \mathrm{m}^{2} \mathrm{sPa}\right.$ or simply $\left.\mathrm{s} / \mathrm{m}\right] . \phi$ is the relative humidity, initial conditions was set to 0.6 through the whole domain, internal boundary condition was set to 0.5 and external 0.9 was used respecting [13].

\section{RESULTS}

An example of the image representation of the numerical simulation results is shown in Fig. 2. We evaluated temperature distribution, heat flux magnitudes, relative humidity and moisture flux magnitudes on all 18 simulated models. Observing Fig. 1., which represents Model 1 with EPS or MW external thermal insulation layer on the façade wall, it is visible that there is no significant difference between the temperature distribution using EPS or MW insulation. There is slight difference visible, when we compare heat flux magnitudes, EPS insulated façade wall's fader-groove connection transfers more heat to the outside, than when MW insulation was applied. This can be explained with MW insulation's better thermal conductivity over EPS. Unlike previous ones, there is outstanding difference between relative humidity and moisture flux magnitudes around the building construction. When observing relative humidity across the sections, it is clearly visible that EPS insulation have higher relative humidity than MW, due to its higher moisture capacity and lower vapour permeability. It is also observable, that EPS insulation results higher relative humidity in the masonry blocks, in closed cell PUR foam sealing and in the fixed wood frame too. High relative humidity decreases thermal performance of the materials by lowering their thermal conductivities. Moisture flux magnitudes are showing very clearly, that moisture flux grow towards the least, minimal vapour resistant route of the construction joints. However while the EPS have lower vapour permeability, it results in moisture accumulation in the masonry block next to the window. On the other hand, MW insulated construction shows greater 
$6^{\text {th }}$

INTERNATIONAL CONFERENCE

Contemporary achievements in civil engineering 20. April 2018. Subotica, SERBIA

moisture bridge next to the window frame and the moisture flux across the masonry blocks are greater too, showing that the building construction can "breathe".

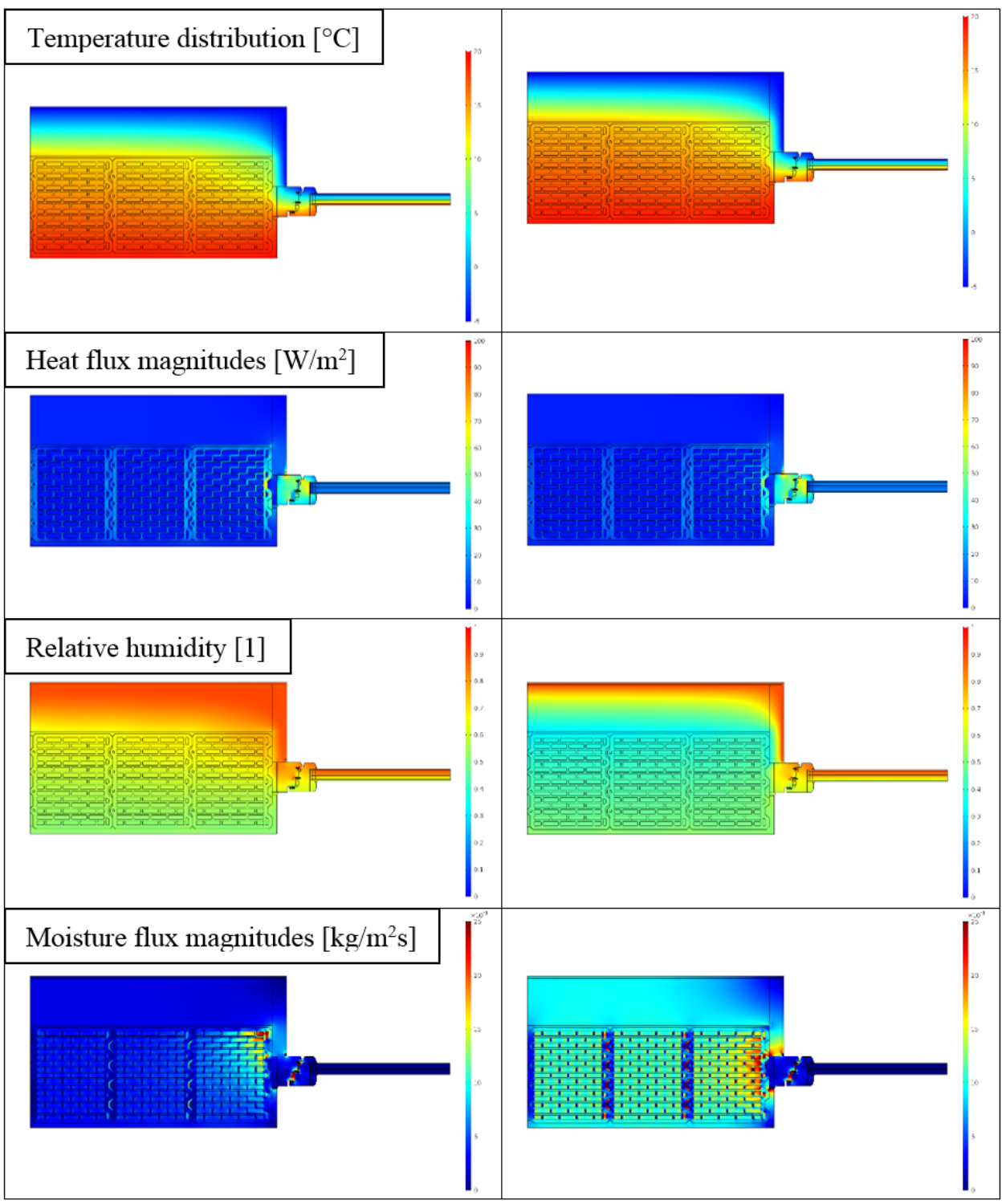

Figure 2. Simulation results of Model 1 with EPS (left) and MW (right) insulation

Besides graphical results, we obtained the minimum internal surface temperatures and calculated the $\mathrm{f}_{\mathrm{RSI}}$ values for the building construction joints according to EN ISO 10211:2017 [16]. We evaluated the moisture content in the thermal insulation layer and 
in the closed cell PUR foam in each joint, and also obtained the average inward heat flux from the internal surfaces of the construction. These results are summarized in Table 1. According to the $\mathrm{f}_{\mathrm{RSI}}$ values, all construction design meet the minimum requirements of $\mathrm{f}_{\mathrm{RSI}}>0.8$ and there is no big differences between the minimum temperatures considering EPS or MW insulation, the differences are smaller than $0.25{ }^{\circ} \mathrm{C}$ in each case. Nevertheless, there is significant differences in the moisture content of the insulation layers and in the open cell PUR foam between construction design and insulation type. At horizontal sections, Model 3 got the best moisture related results and lowest average heat flux too. However, it performed least good at minimum temperatures, and Model 1 performed best. It is visible, that MW insulations have considerably lower moisture contents, than EPS, and PUR foam have lower moisture content, when MW insulation was used. Comparing the windows lintel constructions, which included the internal slab and insulated ascending façade wall joint too, it is visible that Model 1 had the highest minimum surface temperatures which are more than $1{ }^{\circ} \mathrm{C}$ higher, than Model 3 sections. In this case, Model 3 sections have the lowest moisture contents in the insulations and sealing. Moving to the windows still sections, Model 1 and 2 have higher minimum surface temperatures and $\mathrm{f}_{\mathrm{RSI}}$ values than Model 3, but in the insulations, there are large amount of moisture accumulated. In Model 1, both EPS and MW insulation is filled with moisture, in model 2, the moisture content in the external insulation layers are smaller but in the PUR foam is with EPS very high. Average inward heat flux values show great differences between the models. Considering the horizontal section, there is more than 26\% more heat loss from the internal surfaces of Model 1 with EPS than Model 3 with MW. On the heat flux point of view, MW insulated constructions, and Model 3 design shows the lowest results.

Table 1. Temperature, moisture content (MC) and average heat flux results

\begin{tabular}{|l|c|c|c|c|c|}
\hline $\begin{array}{c}\text { Model, section, } \\
\text { thermal insulation }\end{array}$ & $\begin{array}{c}\text { Minimum } \\
\text { internal surface } \\
\text { temperature }\left[{ }^{\circ} \mathrm{C}\right]\end{array}$ & $\begin{array}{c}\mathrm{f}_{\text {RSI }} \\
{[1]}\end{array}$ & $\begin{array}{c}\text { MC in the } \\
\text { insulation } \\
{\left[\mathrm{kg} / \mathrm{m}^{3}\right]}\end{array}$ & $\begin{array}{c}\text { MC in PUR } \\
\text { foam } \\
{\left[\mathrm{kg} / \mathrm{m}^{3}\right]}\end{array}$ & $\begin{array}{c}\text { Avg. inward } \\
\text { heat flux } \\
{\left[\mathrm{W} / \mathrm{m}^{2}\right]}\end{array}$ \\
\hline 1, horizontal, eps & 16.60 & 0.86 & 2.66 & 0.84 & 11.28 \\
\hline 1, horizontal, mw & 16.75 & 0.87 & 0.25 & 0.40 & 10.77 \\
\hline 2, horizontal, eps & 16.44 & 0.86 & 2.61 & 0.88 & 10.47 \\
\hline 2, horizontal, mw & 16.58 & 0.86 & 0.25 & 0.38 & 10.06 \\
\hline 3, horizontal, eps & 15.83 & 0.83 & 2.01 & - & 9.28 \\
\hline 3, horizontal, mw & 15.97 & 0.84 & 0.24 & - & 8.94 \\
\hline 1, lintel, eps & 17.20 & 0.89 & 29.25 & 1.07 & 5.84 \\
\hline 1, lintel, mw & 17.27 & 0.89 & 9.51 & 0.56 & 5.53 \\
\hline 2, lintel, eps & 16.87 & 0.87 & 11.03 & 4.64 & 5.44 \\
\hline 2, lintel, mw & 16.94 & 0.88 & 5.23 & 0.53 & 5.16 \\
\hline 3, lintel, eps & 16.06 & 0.84 & 2.88 & 1.14 & 5.38 \\
\hline 3, lintel, mw & 16.11 & 0.84 & 0.24 & 0.71 & 5.16 \\
\hline 1, sill, eps & 15.95 & 0.84 & 2.08 & 0.39 & 10.57 \\
\hline 1, sill, mw & 16.02 & 0.84 & 0.23 & 0.28 & 10.38 \\
\hline
\end{tabular}


Contemporary achievements in civil engineering 20. April 2018. Subotica, SERBIA

\begin{tabular}{|l|c|c|c|c|c|}
\hline 2, sill, eps & 15.54 & 0.82 & 2.13 & 0.69 & 10.06 \\
\hline 2, sill, mw & 15.76 & 0.83 & 0.23 & 0.28 & 9.75 \\
\hline 3, sill, eps & 15.30 & 0.81 & 2.08 & 1.03 & 9.09 \\
\hline 3, sill, mw & 15.41 & 0.82 & 0.23 & 0.83 & 8.82 \\
\hline
\end{tabular}

Fig. 3. showing heat flux magnitudes in the horizontal sections of Model 1, 2 and 3 with EPS (left side) and MW (right side) insulations. Moisture bridges are clearly observable across the sections. It is also visible, that if we use EPS for external insulation, Model 3 is the best solution possible. It is observable, that with EPS insulation, we can reduce the moisture bridge, if we put the window closer to the external side. With MW, there is a huge moisture bridges between the wood frame and the masonry block, which can be reduced in Model 3 with using appropriate vapour barrier, not only PUR foam. During the simulations, we obtained higher moisture fluxes in MW insulated models, because these models have lower moisture resistances, therefore more moisture can go through them.

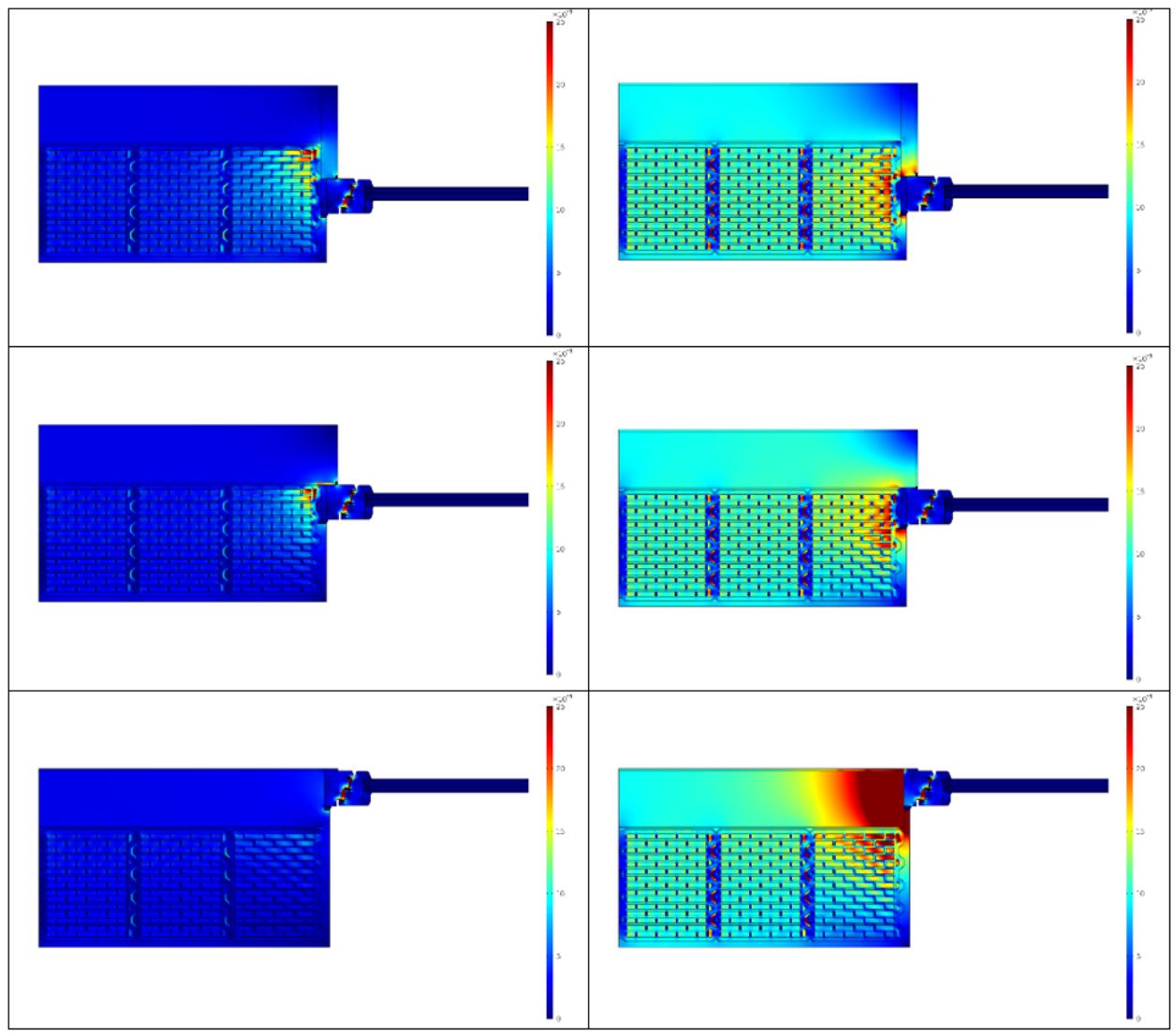

Figure 3. Moisture flux magnitudes $\left[\mathrm{kg} / \mathrm{m}^{2} \mathrm{~s}\right]$ with EPS (left) and MW (right) insulations 
Савремена достигнућа у грађевинарству 20. април 2018. Суботица, СРБИЈА

In Fig. 4. the relative humidity is visible across the sections. Placing the window to the external side is resulting lower relative humidity in the additional thermal insulation layer before the lintel. We can also observe, that using MW insulation results lower relative humidity across the section, compared to EPS insulation, which leads to better thermal performance too. Masonry blocks have visibly lower relative humidity if MW insulation was used in the designed building constructions.

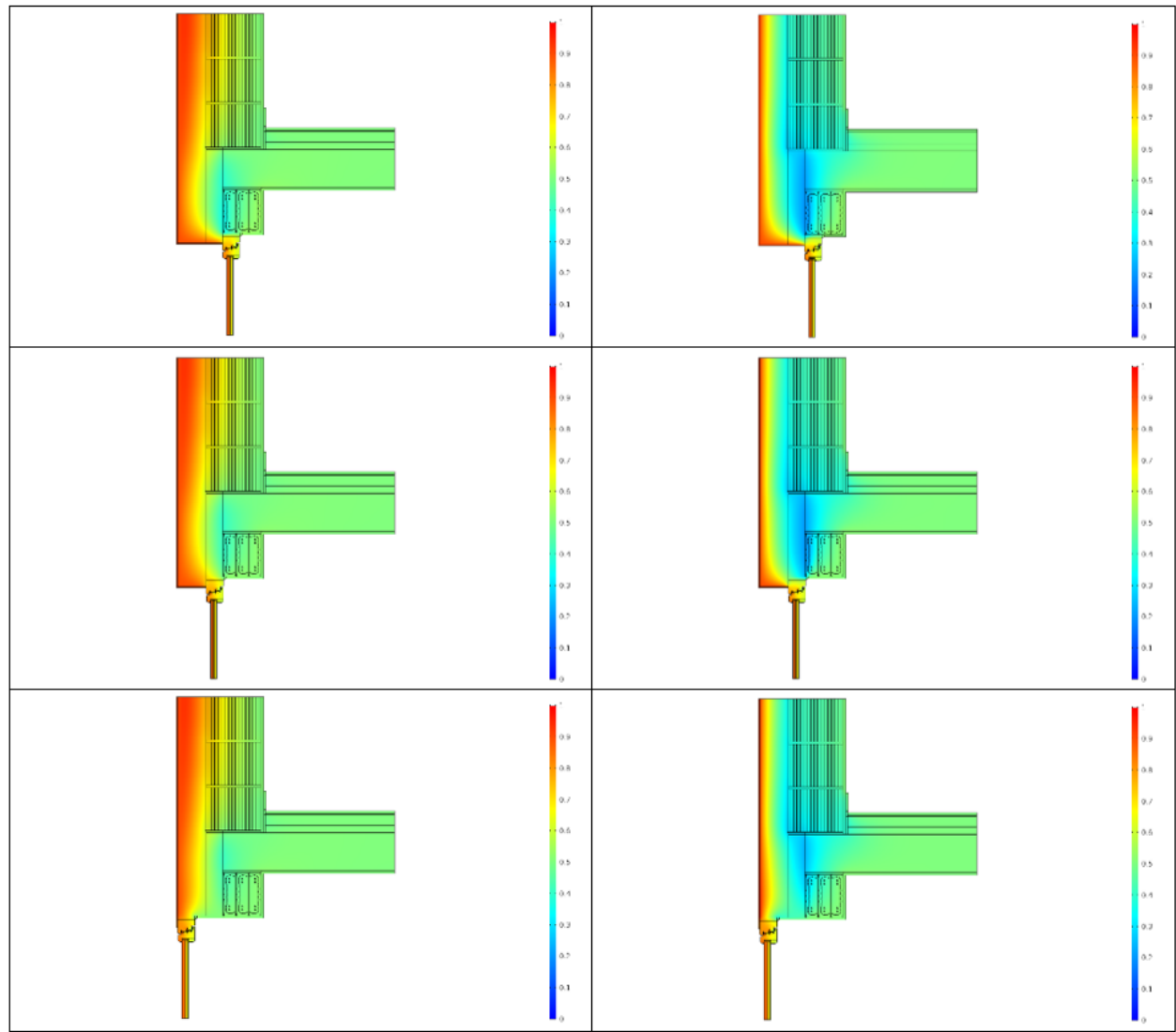

Figure 4. Relative humidity [1] in windows lintel construction joints with internal slab and insulated façade wall with EPS (left) and MW (right) insulations

In the windows sill models, conjugated heat and moisture transfer simulations showed potential condensation risk in the external thermal insulation layers, see Fig. 5. Noncolored surfaces in the models' domain show condensation in the thermal insulation layers. The condensation potential is highest in Model 1 when EPS is used.

Aluminum edging profile is blocking upward moisture transfer and drying of the insulation in Model 1 and Model 2 with both type of external insulations. This phenomena is clearly visible in the data of Table 1. respectively. High relative humidity results higher thermal conductivity, and condensation in the thermal insulation layer 
Contemporary achievements in civil engineering 20. April 2018. Subotica, SERBIA

decreases not just its thermal performance, but its life expectancy as well. Construction design Model 3 is the only option to be considered safe against moisture damages according to our investigation in this case. Since heat and moisture transport simulations have shown a varying degree of condensation risk in the outer heat insulating layers and between the wood frame and the masonry element, life expectancy and building-building capabilities must be considered in addition to thermal performance.

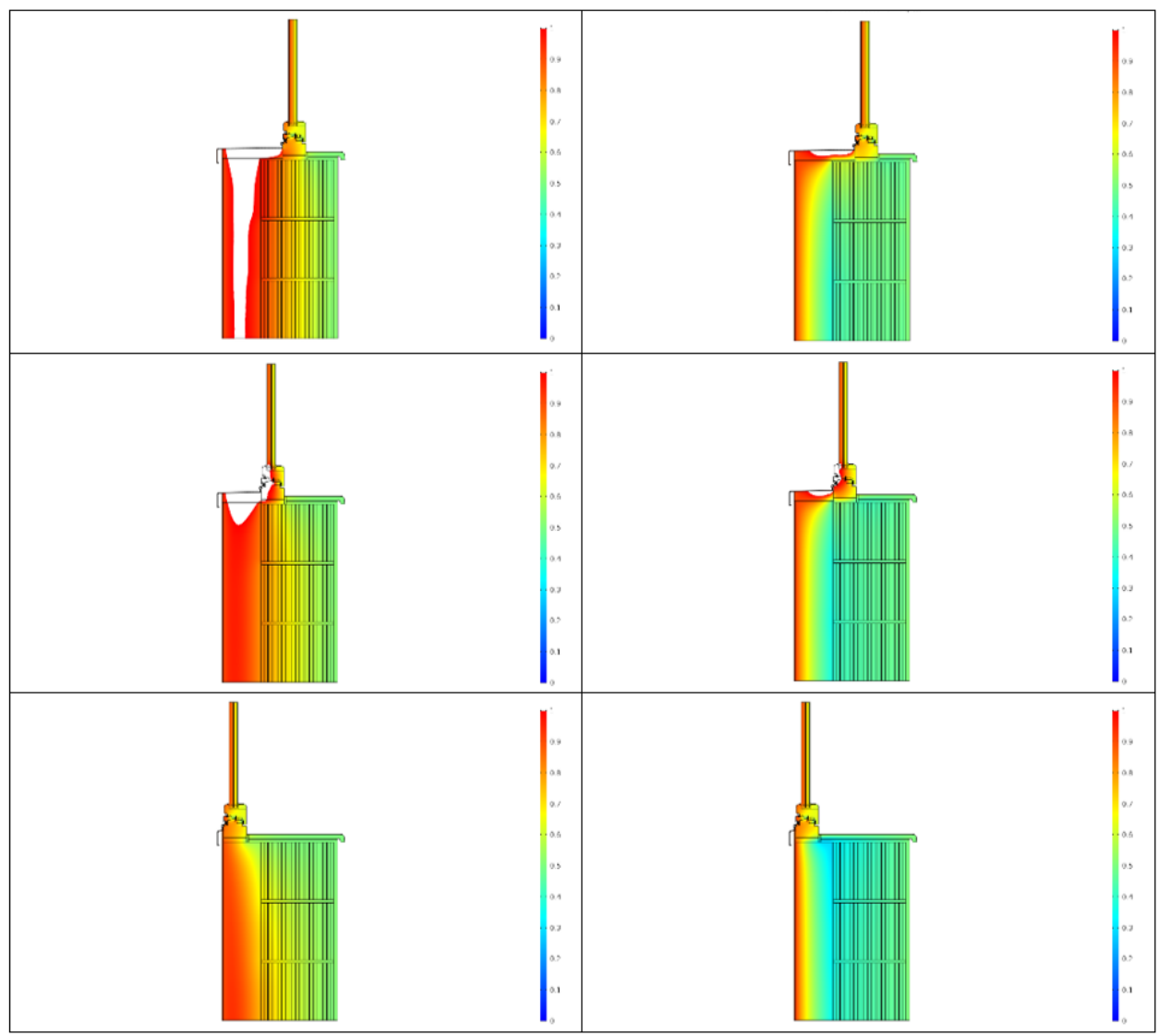

Figure 5. Relative humidity [1] in windows sill construction joints with insulated façade wall with EPS (left) and MW (right) insulations

\section{CONCLUSIONS}

Based on our investigations, we can state that the exact location of the windows on the facade and the applied materials significantly affect the building constructions hygrothermal performance, which can affect the entire building's performance as well. It is therefore important to consider the hygrothermal performance of building 
6. МЕЂУНАРОДНА КОНФЕРЕНЦИЈА

Савремена достигнућа у грађевинарству 20. април 2018. Суботица, СРБИЈА

constructions together the architectural and structural design. When examining surface temperatures, the difference is negligible, but when observing inward heat fluxes, windows placed to the outer side with MW insulation had up to $26 \%$ less heat loss, than the other joints. There are great differences in the moisture content of the applied insulation and in the seal between the investigated models. After comparing the results, we can state that the most ideal case if the window is placed on the outside and MW insulation is applied. Using this type of construction can avoid moisture damages besides the good thermal performance.

\section{REFERENCES}

[1] International Energy Outlook 2016, U.S. Energy Information Administration (EIA), Washington, USA, 2016.

[2] MacKay, J.C.D.: Sustainable Energy - without the hot air, UIT Cambridge Ltd., Cambridge, England, 2009.

[3] Energy Roadmap 2050, European Commission, Brussels, Belgium, 2011.

[4] Arcipowska, A, Anagnostopoulos, F, Mariottini, F, Kunkel, S, Energy Performance Certificates Across The EU: A Mapping of National Approaches, Buildings Performance Institute Europe (BPIE), Brussels, Belgium, 2014.

[5] 7/2006. (V.24.) TNM Decree on the Determination of the Energy Characteristics of Buildings

[6] Bakonyi, D., Dobszay, G.: Simplified calculation of non-repeating thermal bridges of the typical Central-European small suburban houses, Pollack Periodica, 2016., vol. 11, № 3, p.p. 43-60.

[7] Nagy, B.: Comparative Analysis of Multi-Dimensional Heat Flow Modeling, Proceedings of the Second International Conference for PhD Students in Civil Engineering and Architecture, 2014., p.p. 468-476.

[8] Tömböly, C.: Problems Caused by Thermal Bridges around Windows of Historic Buildings and Renovation Methods, Acta Technica Jaurinensis, 2017., vol. 10, № 1, p.p. 59-69.

[9] EN 15026:2007 Hygrothermal performance of building components and building elements. Assessment of moisture transfer by numerical simulation.

[10] Comsol Multiphysics 5.3a user’s manual, 2017.

[11] WUFI 6 PRO database, 2018.

[12] EN ISO 10077-2:2012 Thermal performance of windows, doors and shutters. Calculation of thermal transmittance. Part 2: Numerical method for frames (ISO 10077-2:2012)

[13] MSZ 24140:2015 Power engineering dimensioning calculuses of buildings and building envelope structures

[14] Künzel, H.M.: Simultaneous Heat and Moisture Transport in Building Components. - One- and twodimensional calculation using simple parameters, IRB Verlag, 1995.

[15] Nagy, B., Tóth, E.: Hygrothermal behaviour of hollow and filled ceramic masonry blocks, RILEM Proceedings PRO, 2016., vol. 112, p.p. 279-288.

[16]EN ISO 10211:2017 Thermal bridges in building construction - Heat flows and surface temperatures - Detailed calculations. (ISO 10211:2017) 